DOI: $10.46340 /$ eppd.2021.8.3.24

Hanna Nikitina-Dudikova, PhD in Law

ORCID ID: https://orcid.org/0000-0002-8865-0061

National Academy of Internal Affairs, Ukraine

\title{
TRACE EVIDENCE OF CRIMES AGAINST SEXUAL FREEDOM AND SEXUAL INTEGRITY OF CHILDREN
}

\author{
Ганна Нікітіна-Дудікова, к. ю. н. \\ Національна академія внутрішніх справ, Україна \\ СЛІДОВА КАРТИНА ЗЛОЧИНІВ ПРОТИ \\ СТАТЕВОЇ СВОБОДИ ТА СТАТЕВОЇ \\ НЕДОТОРКАНОСТІ ДІТЕЙ
}

The article is devoted to the study of traces of crimes against sexual freedom and sexual integrity of children. The article outlines groups of traces, depending on the source of information storage, which constitute three large groups: ideal traces, material traces and electronic (digital) traces. It turns out that the most informative set of traces that are found at the crime scene and are the starting point for further development of versions, are material traces, among which are traces of reflection, traces of substances and odors. It is emphasized that in the investigation of the studied category of crimes, special attention is paid to traces-substances of biological origin, which may contain human genomic information and later become the object of molecular genetic research to identify a person. Objects that may contain nuclear DNA include blood, saliva, semen, hair, bones, teeth, nails, subungual contents, other tissues, organs, or parts of the body. It was found that traces of blood were found during the investigation of crimes against sexual freedom and sexual integrity of children in most cases in the form of spots and in the form of prints. It is emphasized that traces of semen should be looked for on the body of the victim, his clothes and possible items of wiping by the offender. Saliva is found on the underwear of the offender and the victim in the case of rape by orogenital penetration. It is outlined that hair among the traces of biological origin belong to the traces-objects, which, having the property of localization on the objects-carriers, have a certain shape. It is noted that traces of sweat and fat sweat do not contain cells with nuclei, however, due to contact with physical evidence, along with traces of sweat and fat sweat can get cells containing nuclei. It is concluded that traces of human biological origin can be identifying objects for further identification of a person who has committed crimes against sexual freedom and sexual integrity of children. The concept of ideal traces and their significance in the investigation of crimes against sexual freedom and sexual integrity of children are highlighted, attention is paid to the features of ideal traces left in the child's memory. The issue of electronic (digital) traces is covered, which, depending on their information content, can be divided into traces of preparation for the commission of a crime and traces of the direct commission of a crime. The forensic significance of traces of correspondence on social networks and SMS messages is outlined.

Keywords: crimes against sexual freedom and sexual integrity of children, material traces, ideal traces, electronic traces, blood, saliva, sperm, hair.

Постановка проблеми. Злочини проти статевої свободи та статевої недоторканості дітей набувають все більшого поширення. Статистика свідчить про зростання кількості злочинів проти статевої свободи та статевої недоторканості, потерпілими від яких є неповнолітні та малолітні особи.

Згідно відомостей Єдиного звіту про кримінальні правопорушення Офісу Генерального прокурора за січень-грудень 2019 року ${ }^{1}$ було обліковано 352 кримінальних провадження за ознаками

${ }^{1}$ Генеральна прокуратура України (2021). Сдиний звіт про кримінальні правопорушення <https://old.gp.gov.ua/ua/stst2011.html?dir_id=113897\&libid=100820> (2021, травень, 18). 
злочину, передбаченого ст. 152 КК України - згвалтування, з яких потерпілими були 56 неповнолітніх і 92 малолітніх особи. У 2020 році було обліковано 388 кримінальних проваджень за фактом вчинення згвалтування, з яких потерпілими були 82 неповнолітніх та 151 малолітні особи ${ }^{1}$.

Наведені статистичні відомості свідчать про зростання кількості неповнолітніх та малолітніх потерпілих при відносній сталості вчинення загальної кількості злочинів проти статевої свободи та статевої недоторканості. Тому, актуальним $є$ розроблення методики розслідування злочинів проти статевої свободи та статевої недоторканості дітей.

Важливе значення уметодиці розслідування злочинів має слідова картина як елемент криміналістичної характеристики, який являє собою відображення механізму злочину у слідовій інформації. Дослідження кожного сліду, виявленого на місці події, та слідової картини в цілому дозволяє відтворити уявну модель злочину, послідовність вчинених злочинцем дій, особу злочинця, знаряддя вчинення злочину, викрити неправдиві показання свідка або злочинця. Слідова картина злочину $є$ початковою відправною точкою у висуненні версій та розслідуванні кримінального провадження.

Проблематика слідів вчинення злочину була предметом наукових досліджень Д.В. Пашнєва ${ }^{2}$ Д.В. Затенацького ${ }^{3}$, Г.В. Мудрецької ${ }^{4}$, А.В. Реуцького ${ }^{5}$.

Проблеми розслідування злочинів проти статевої свободи та статевої недоторканості дітей були предметом наукових досліджень у працях М.В. Корнієнка ${ }^{6}$, Є.С. Хижняка ${ }^{7}$.

Проте сліди вчинення злочинів проти статевої свободи та статевої недоторканості дітей як частини криміналістичної методики, на нашу думку, досліджено не повною мірою.

Meта cmammi. Розкрити види та характеристику слідів вчинення злочину при розслідуванні злочинів проти статевої свободи та статевої недоторканості дітей.

Виклад основного матеріалу. Цілісною системою речових джерел кримінально-релевантної інформації, яка виникла в результаті взаємодії матеріальних елементів події відображає обставини й механізм розслідуваної події та використовується для формування динамічної моделі механізму даної події на відповідних стадіях процесу розслідування злочину є його слідова картина.

У злочинах проти статевої свободи та статевої недоторканості дітей функціональність поняття слідової картини характеризується тим, що воно представляє об'єкт як цілісну систему, що дозволяє застосувати до нього методологію системного аналізу. Динамічність поняття слідової картини обумовлена взаємозв'язком цього поняття з поняттям слідчої (експертної, оперативно-розшукової) версії. Будь-яка зміна початкової інформації, що міститься в слідовій картині, веде до модифікації версійної структури i, навпаки, - виникнення нової версії призводить до перегляду змісту й обсягу слідової картини 8 .

Сліди злочину, тобто зміни, що відбуваються в органічній та неорганічній природі і $\epsilon$ складовою частиною слідової картини, традиційно в криміналістиці поділяються на дві категорії: матеріальні та ідеальні (нематеріальні). Матеріальними слідами (простими формами відображення злочину) є зміни у неживій природі у вигляді відбитків, різного роду руйнувань, пошкоджень,

\footnotetext{
1 Там само.

2 Пашнєв, Д. В. (2007). Використання спеціальних знань при розслідуванні злочинів, вчинених із застосуванням комп’ютерних технологій: автореферат дисертації на здобуття наукового ступеня кандидата юридичних наук. Харків: Харківський національний університет внутрішніх справ.

3 Затенацький, Д. В. (2008). Ідеальні сліди в криміналістиці (техніко-криміналістичні та тактичні прийоми їх актуалізаціі): автореферат дисертації на здобуття наукового ступеня кандидата юридичних наук. Харків: Національний юридичний університет імені Ярослава Мудрого.

${ }^{4}$ Мудрецька, Г. В. (2011). Методика розслідування викрадень бюджетних коштів: автореферат дисертації на здобуття наукового ступеня кандидата юридичних наук. Ірпінь: Національний університет державної фіскальної служби України.

${ }_{5}^{5}$ Реуцький, А. В. (2009). Методика розслідування злочинців у сфері виготовлення та обігу платіжних карток: автореферат дисертації на здобуття наукового ступеня кандидата юридичних наук. Харків: Національний юридичний університет імені Ярослава Мудрого.

${ }^{6}$ Корнієнко, М. В. (2019). Концеептуальні основи протидї̈ насильницьким злочинам щзодо дітей. Одеса:

Одеський державний університет внутрішніх справ.

${ }^{7}$ Хижняк, Є. С. (2013). Особливості розслідування статевих злочинів щодо малолітніх: дисертація на здобуття наукового ступеня кандидата юридичних наук. Одеса: Міжнародний гуманітарний університет. 8 Дикунов, А. И. (2005). Криминалистический анализ следовой картины расследуемого события с признаками преступления: диссертация на соискание научной степени кандидата юридчческих наук. Москва: МГУ.
} 
деформацій об’єктів, а також нашарувань та відшарувань. Більш складною формою змін середовища $\epsilon$ ідеальні сліди, що мають психофізіологічну природу і проявляються у вигляді виникаючих у свідомості людей думок, образів та окремих моментів злочину, що закріпилися у пам'яті ${ }^{1}$.

Розглядаючи злочини проти статевої свободи та статевої недоторканості дитини, в світлі гносеологічного підходу до поділу слідів в залежності від джерела збереження інформації, реалії сучасного світу змушують виділяти ще один вид слідів вчинення злочину- у формі змін у інформаційному середовищі, тобто за допомогою використання комп'ютерної техніки та засобів мобільного зв'язку.

Отже, сліди вчинення статевих злочинів щодо дитини можна поділити не на традиційні дві, а на три великі групи: ідеальні сліди, матеріальні сліди та електронні (цифрові) сліди.

Найбільш інформативною сукупністю слідів, які виявляються на місці вчинення злочину та $\epsilon$ відправною точкою для подальшого висунення версій $\epsilon$ матеріальні сліди. 3 аналізу матеріалів кримінальних проваджень вбачається, що матеріальні сліди були виявлені та вилучені у 97,3\% випадків.

Матеріальні сліди є речовими джерелами криміналістичної інформації, до них відносяться будь-які предмети матеріального світу, які здатні нести відомості про фактичні обставини злочину, тобто доказову інформацію2 .

Серед матеріальних слідів вчинення злочинів проти статевої свободи та статевої недоторканості дитини можна виділити сліди-відображення, сліди-речовини та запахові сліди.

Найпоширенішими видами слідів-відображень вчинення зазначеного злочину є сліди людини, а саме: сліди рук, сліди ніг, сліди губ, зубів, нігтів. Окремо варто виділити сліди, що залишаються на тілі потерпілої особи внаслідок статевого акту: ознаки порушення статевої недоторканості (незайманості); садна, крововиливи в області статевих органів, на стегнах, руках, спині, ушкодження порожнини рота при орально-генітальних контактах тощо; наслідки статевого акту (вагітність, зараження хворобами, що передаються статевим шляхом); сперма та інші об'єкти біологічного походження ${ }^{3}$.

Однак при розслідуванні досліджуваної категорії злочинів особливу увагу на себе звертає саме сліди-речовини. У більшості випадків, сліди-речовини біологічного походження можуть містити у собі геномну інформацію людини та стати у подальшому об'єктом молекулярно-генетичного дослідження з метою ідентифікації особи.

На даний час в Україні досліджується ядерна ДНК, тобто, для молекулярно-генетичного дослідження підходить будь-який біоматеріал, який містить клітини 3 ядрами. До таких об'єктів відносяться: кров, слина, сперма, волосся, кістки, зуби, нігті, піднігтьовий вміст, інші тканини, органи, або окремі частини тіла.

Сліди крові були виявлені під час розслідування злочинів проти статевої свободи та статевої недоторканості дітей у 40,5\% досліджених нами матеріалів кримінального провадження. У більшості випадків, сліди крові були залишені у формі плями (47,8\%) та у формі відбитку (40\%).

При виявленні крові на місці події звертається увага на величину і форму слідів, із яких можна говорити про механізм їх утворення і про обставини події4.

3'ясування способу утворення слідів крові за їх особливостями дозволяє визначити джерело кровотечі, положення в просторі тіла або предмета, на який потрапила кров, зміну цього положення i його послідовність, напрямок руху крапель крові і відстань, з якої вона потрапила на тіло або предмет, черговість нанесення ушкоджень, що супроводжувалися зовнішньою кровотечою, переміщення і позу потерпілої особи в момент стікання з неї крові, заходи, які вживалися для видалення крові 5 .

При вчиненні статевих злочинів сліди крові можуть залишитись внаслідок здійснення опору неповнолітнього потерпілого та його подолання злочинцем, шляхом застосування фізичної сили. Тому форми та види слідів крові дозволяють встановити спосіб подолання опору потерпілого та спосіб

\footnotetext{
${ }^{1}$ Крылов, И. В. (2010). Совершение преступлений в условиях неочевидности. Бизнес в законе, 5 , 82-85.

2 Ткач, О. В. (2015). Слідова картина як джерело доказової інформації при розслідуванні порушень недоторканності приватного життя. Вісник кримінального судочинства, 4, 192-197.

${ }^{3}$ Кухарьков, Ю. В., Пучков, Г. Ф., Доморацкая, Т. Л., Тепляшина, И. С. (2001). Медико-правовые аспекты сексуального насилия. Минск.

${ }^{4}$ Нікітіна-Дудікова, Г. Ю. (2015). Слідова картина насильницького задоволення статевої пристрасті неприродним способом, вчиненого стосовно малолітньої особи. Прикарпатський юридичний вісник, 3 (2), $234-239$.

${ }^{5}$ Перлін, С. І. Шевцов, С. О. Косміна, Н. М. Іонова, В. В. (2009). Огляд місия подї: виявлення та вилучення об'єктів біологічного походження. Харків: Чальцев О. В.
} 
вчинення злочину ${ }^{1}$. При згвалтуванні, сексуальному насильстві та інших статевих злочинах сліди крові виявляються в області застібки штанів і на нижній білизні. Особливу увагу при виявленні частинок крові слід звертати на вміст під нігтями. Злочинець майже завжди руками береться за статеві органи потерпілої, нерідко їх пошкоджує і з виникаючих ранок кров потрапляє під його нігті. Під нігтями кров зберігається тривалий час ${ }^{2}$.

Найбільш ймовірно знайти сліди крові в ванних кімнатах, раковинах і т.д., що пов’язується з їх можливим неповним знищенням в цих місцях. Бризки можуть утворитися від струшування крові з закривавлених рук. Також не можна виключати того факту, що сам злочинець міг бути поранений внаслідок опору потерпілої.

Оскільки досліджуваний нами вид злочинів направлених проти статевої свободи та статевої недоторканості дітей, то виявлення слідів сперми є закономірним процесом. Як правило, у справах проти статевої свободи та статевої недоторканості дитини сліди сперми, в першу чергу, слід шукати на тілі потерпілої особи (у 45,5\% випадків), ії одязі (у 40,1\% випадків) та на можливих предметах обтирання злочинцем (у $15,6 \%$ випадків).

Однак виявлені сліди сперми меншою мірою стають об'єктами молекулярно-генетичного дослідження, тому що для успішного дослідження зразка сперми на ДНК аналіз, рідкий зразок сперми потрібно як найшвидше висушити на марлевій серветці, оскільки в рідкій спермі деградація ДНК відбувається значно швидше ніж у крові, а збереження сперми в замороженому стані приводить до руйнування сперматозоїдів.

Сперму виявляють візуально на одязі, вона нагадує висохлий крохмаль, клейстер та жорстка на дотик ${ }^{3}$. Вилучаються сліди сперми разом з об’єктом-носієм (труси, штани і т.д.). Якщо вони виявлені, в ході огляду, на тілі людини, то вилучаються на липку стрічку, дактоплівку, з інших об'єктів беруть зіскрібки.

Наступним видом слідів біологічного походження, які входять до слідової картини злочинів проти статевої свободи та статевої недоторканості дитини та містять геномну інформацію людини, $\epsilon$ слина та букальний епітелій. Слина - це секрет слинних залоз людини, що виділяється в ротову порожнину і бере участь у травленні, $є$ мутнуватою грузлою рідиною через наявність клітинних елементів. Ї̈̈ висохлі сліди на темних предметах мають злегка білуватий колір. Вона містить генетично зумовлені маркери, за якими можна виявити ідентифікуючі ознаки людини, що залишила сліди.

У більшості випадків, слину виявляють на спідній білизні злочинця та потерпілої особи у разі вчинення згвалтування шляхом орогенітального проникнення (17,3\% випадків).

Волосся серед слідів біологічного походження відносяться до слідів-предметів, які, мають властивість локалізації на предметах-носіях, мають певну форму, що й обумовлює їх пошук. При вчиненні статевих злочинів, внаслідок здійснення опору, волосся може залишатися на руках злочинця чи потерпілого, на одязі, на знаряддях злочину, на місці вчинення злочину.

До особливостей виникнення цих слідів можна віднести контактну взаємодію: потерпілий, захищаючись, вириває волосся з голови, бороди, вусів, лобка і інших частин тіла злочинця, які можуть бути згодом знайдені в руках, на тілі або одязі потерпілого.

На сучасному етапі розвитку судової медицини і експертної практики за морфологічними ознаками неможливе встановлення приналежності досліджуваного волосся певній особі. Тому, доказове значення окремо виявленого волоса, навіть якщо визначені індивідуальні морфологічні характеристики і мікроелементний склад, здебільшого істотно переоцінюється ${ }^{4}$. Однак, клітини з ядрами містяться в піхвових оболонках цибулин волосин та можуть бути об'єктами молекулярногенетичного дослідження 5 .

Також на місці події можна виявити сліди поту та жиропоту. Сліди поту та жиропоту клітин з ядрами не містить. Однак у чистому вигляді вони не виявляються, а в основному їх сліди на речових

\footnotetext{
${ }^{1}$ Нікітіна-Дудікова, Г. Ю. (2015). Слідова картина насильницького задоволення статевої пристрасті неприродним способом, вчиненого стосовно малолітньої особи. Прикарпатський юридичний вісник, 3 (2), 234-239.

${ }^{2}$ Скорченко, Н. Т. (2004). Расследование изнасилований. Москва: Былина.

${ }^{3}$ Перлін, С. І. Шевцов, С. О. Косміна, Н. М. Іонова, В. В. (2009). Огляд місия події: виявлення та вилучення об'єктів біологічного походження. Харків: Чальцев О. В.

${ }^{4}$ Колдина, В. Я. (ред.) (1985). Естественнонаучная криминалистика. Москва: Юридическая литература.

${ }^{5}$ Бурчинський, В. Г., Дем'янчук, А. П., Хохолєва, Т. В. та ін. (2012). Використання ДНК-аналізу у судовомедичних експертизах речових доказів та експертизах спірного батьківства (материнства, підміни дітей). Київ.
} 
доказах. Тобто, це сліди, що утворювалися не від короткочасного контакту із шкірою людини, а протягом якогось певного часу. За цей час відбувався тісний контакт шкіри з предметом, навіть тертя по шкірі, внаслідок різних причин на шкірі за цей час могли утворитися мікроушкодження, які не викликають будь-яких відчуттів у людини і невидимі оком, але із базального шару шкіри на речові докази можуть попадати клітини, що містять ядра. I як показали експериментальні дослідження, зокрема, проведені у відділенні судово-медичної цитології, в таких слідах дійсно виявляються ядровмісні клітини ${ }^{1}$.

Отже, сліди біологічного походження, які містять геномну інформацію людини та можуть бути об'єктами ДНК дослідження, мають велике значення для успішного розслідування злочинів проти статевої свободи та статевої недоторканості дітей, оскільки надають можливість ідентифікації особи за залишеними ним слідами.

Іншою групою слідів в залежності від джерела збереження є ідеальні сліди. Ідеальні сліди - це сліди у свідомості людини, що $є$ специфічною формою вищого рівня психічного, цілеспрямованого, активного, вибіркового відображення, здійснюваного в чуттєво-раціональній формі, у результаті якого формується відносно адекватний, суб'єктивно-об' єктивний «відбиток» - уявний образ у пам'яті людини, заснований на раніше сприйнятій інформації, та є формою збереження відповідної інформації².

Особливістю ідеальних слідів у злочинах проти статевої свободи та статевої недоторканості дитини $є$ те, що вони виявляються у $100 \%$ випадків, незалежно від наявності чи відсутності фізичного контакту між потерпілим та злочинцем. В залежності від процесуального статусу особи ідеальні сліди можуть залишатися у пам'яті потерпілої особи, свідка чи підозрюваного.

Однак під час розслідування злочинів проти статевої свободи та статевої недоторканості дітей, важливо враховувати вік потерпілої особи (малолітній чи неповнолітній). На сприйняття інформації про подію та обставини, за яких вона відбувалась суттєво впливають умови, за яких вона сприймалась дитиною. До таких умов належать: відстань від місця події (у разі якщо ідеальний слід сформований у свідка), перспектива сприйняття об'єктивної реальності (наприклад, дитина, яка нижча зростом, сприйматиме більшість дорослих осіб як високих та великих), тривалість дії подразнюючих факторів, елементи, що перешкоджають у сприйнятті інформації (наприклад, розташування потерпілого у положенні, при якому він не зміг розгледіти злочинця), освітлення, можливість сприйняття інформації за допомогою різних аналізаторів (зір, слух, нюх, дотик).

Порівняно новою групою слідів $є$ електронні (цифрові) сліди, тобто будь-яка криміналістично значиму комп'ютерну інформацію, відомості (повідомлення, дані), які перебувають в електронноцифровій формі та зафіксовані на матеріальному носії або передаються каналами зв'язку за допомогою електромагнітних сигналів ${ }^{3}$.

3 аналізу матеріалів кримінальних проваджень вбачається, що електронні (цифрові) докази були виявлені у 52,5\% випадків.

Електронні (цифрові) сліди вчинення злочину проти статевої свободи та статевої недоторканості дитини, в залежності від їх інформаційного змісту, можна поділити на сліди підготовки до вчинення злочину та сліди безпосереднього вчинення злочину.

До слідів підготовки до вчинення злочину можна віднести: сліди пошукових запитів злочинця, направлених на вибір потенційної жертви, інформації щодо можливостей вчинення злочину, вибір місця вчинення злочину, перегляд дитячої порнографії, переписка між потерпілою особою та злочинцем 3 метою іх зустрічей чи на інтимні теми, надсилання злочинцем зображень чи відеозаписів порнографічного характеру потерпілому, фотографій статевих органів злочинця тощо. Слідами безпосереднього вчинення злочину проти статевої свободи та статевої недоторканості дитини можуть бути аудіо-, відеозаписи злочинних дій, листування між потерпілим та злочинцем після вчинення злочину.

Особливу увагу звертає на себе електронні (цифрові) сліди у вигляді листування між злочинцем та потерпілим у соціальних мережах та sms-повідомленнях. Досліджуючи взаємодію між злочинцем та потерпілою усоціальних мережах, корисною може стати інформація про ідентифікатор підозрюваного (ID), а також інформація з листування користувачів та інша інформація, наприклад,

\footnotetext{
1 Там само.

2 Затенацкий, Д. В. (2006). Идеальные следы в криминалистике. Проблеми законності, 78, 177-178.

${ }^{3}$ Вехов, В. Б. (2008). Криминалистическое учение о компьютерной информации и средствах ее обработки: автореферат дисертации на соискание научной степени доктора юридических наук. Волгоград: Волгоградская Академия Государственной Службы.
} 
зображення, які викладаються користувачами, оскільки вони можуть містити метадані з інформацією про дату та час створення зображення, місце його створення тощо ${ }^{1}$. Під час листування у соціальних мережах залишається значна кількість слідів: реєстраційні дані доменного імені, лог-файли (текстові файли, які містять у собі системну інформацію про дії, що відбулися на сервері), дані акаунта користувача, сліди взаємодії (налаштування) з хостинг-провайдером, сліди реклами веб-сайта, прив'язка сторінки соціальної мережі до електронної адреси чи номера мобільного телефону, архів повідомлень, в якому може міститися переписка з потерпілими, статистика активності на сторінці.

Важливу криміналістично значущу інформацію можна отримати при вивченні даних електронного листування і сервісів обміну SMS повідомленнями. В атрибутах файлів електронних листів міститься дата і час відправлення, електронна адреса відправника, найменування та адреса інтернет провайдера та інша інформація. Телефонні дзвінки з мобільного телефону і тексти SMS повідомлень автоматично фіксуються і накопичуються на сервері оператора мобільного зв'язку².

Висновки. Слідова картина $є$ практичним інструментом і своєрідним орієнтиром у виборі напрямів розслідування злочинів проти статевої свободи та статевої недоторканості дітей, оскільки надає вихідну інформацію для висунення слідчих версій про подію злочину.

Сліди вчинення злочинів проти статевої свободи та статевої недоторканості дітей в залежності від джерела слідоутворення можна поділити на три великі групи: ідеальні сліди, матеріальні сліди та електронні (цифрові) сліди.

Матеріальні сліди вчинення злочинів $є$ найбільш інформативною сукупністю слідів, які виявляються на місці вчинення злочину та $є$ відправною точкою для подальшого висунення версій, серед яких можна виділити сліди-відображення, сліди-речовини та запахові сліди.

При розслідуванні досліджуваної категорії злочинів особливу увагу на себе звертає саме слідиречовини. У більшості випадків, сліди-речовини біологічного походження можуть містити у собі геномну інформацію людини та стати у подальшому об'єктом молекулярно-генетичного дослідження з метою ідентифікації особи, оскільки сліди біологічного походження, які містять геномну інформацію людини. Однак для повноцінної та успішної ідентифікації особи за залишеними нею слідами біологічного походження необхідне впровадження єдиної бази геномної інформації людини, яка дозволить розширити пошукове коло осіб та проводити ідентифікацію не в рамках лише одного кримінального провадження.

Ідеальні сліди як відображення елементів навколишнього середовища у свідомості людини у злочинах проти статевої свободи та статевої виявляються у 100\% випадків, незалежно від наявності чи відсутності фізичного контакту між потерпілим та злочинцем. Проте для успішного використання їх у розслідуванні кримінального провадження необхідно враховувати особливості сприйняття об'єктивної реальності неповнолітньою чи малолітньою дитиною.

Електронні (цифрові) сліди мають $є$ порівняно новою групою слідів, однак, з розвитком телекомунікаційних технологій набувають все більшого значення. При розслідуванні злочинів проти статевої свободи та статевої недоторканості дітей електронні (цифрові) сліди в залежності від їх інформаційного змісту, можна поділити на сліди підготовки до вчинення злочину та сліди безпосереднього вчинення злочину. Однак проблемними питанням $є$ фіксація та вилучення електронних слідів з дотриманням кримінальної процесуальної форми, з метою подальшого використання їх як електронних (цифрових) доказів.

\section{References:}

1. Heneralna prokuratura Ukrainy [The General Prosecutor of Ukraine] (2021). Yedynyi zvit pro kryminalni pravoporushennia [Unified report on criminal offenses]

<https://old.gp.gov.ua/ua/stst2011.html?dir_id=113897\&libid=100820> (2021, May, 18). [in Ukrainian].

2. Pashniev, D. V. (2007). Vykorystannia spetsialnykh znan pry rozsliduvanni zlochyniv, vchynenykh iz zastosuvanniam kompiuternykh tekhnolohii [Use of specialized knowledge in the investigation of crimes committed with the use of computer technology]: avtoreferat dissertatsii na soiskaniye nauchnoy stepeni kandidta yuridicheskikh nauk [dissertation abstract for the scientific degree of $\mathrm{PhD}$ of Law]. Kharkiv [in Ukrainian].

\footnotetext{
${ }^{1}$ Корнейко, О. В. (заг. ред.) (2020). Використання електронних (цифрових) доказів у кримінальних провадженнях. Київ: Національна академія внутрішніх справ.

${ }^{2}$ Авдєєва, Г. К., Стороженко, С. В. (2017). Електронні сліди: поняття та види. Вісник Луганського державного університету внутрішніх справ імені Е. О. Дідоренка, 1 (77), 169-176.

$<$ https://journal.lduvs.lg.ua/index.php/journal/article/view/341> (2021, травень, 18).
} 
3. Zatenatskyi, D. V. (2008). Idealni slidy v kryminalistytsi (tekhniko-kryminalistychni ta taktychni pryiomy yikh aktualizatsii) [Ideal traces in criminology (forensic and tactical methods of their actualization)]: avtoreferat dissertatsii na soiskaniye nauchnoy stepeni kandidta yuridicheskikh nauk [dissertation abstract for the scientific degree of PhD of Law]. Kharkiv [in Ukrainian].

4. Mudretska, H. V. (2011). Metodyka rozsliduvannia vykraden biudzhetnykh koshtiv [Methods of investigating theft of budget funds]: avtoreferat dissertatsii na soiskaniye nauchnoy stepeni kandidta yuridicheskikh nauk [dissertation abstract for the scientific degree of $\mathrm{PhD}$ of Law]. Irpin. [in Ukrainian].

5. Reutskyi, A. V. (2009). Metodyka rozsliduvannia zlochyntsiv u sferi vyhotovlennia ta obihu platizhnykh kartok [Methods of investigation of criminals in the field of production and circulation of payment cards]: avtoreferat dissertatsii na soiskaniye nauchnoy stepeni kandidta yuridicheskikh nauk [dissertation abstract for the scientific degree of PhD of Law]. Kharkiv [in Ukrainian].

6. Korniienko, M. V. (2019). Kontseptualni osnovy protydii nasylnytskym zlochynam shchodo ditei [Conceptual bases of counteraction to violent crimes against children]. Odesa: Odes. Derzh. un-t vnutr. sprav [in Ukrainian].

7. Khyzhniak, Ye. S. (2013). Osoblyvosti rozsliduvannia statevykh zlochyniv shchodo malolitnikh [Features of the investigation of sexual crimes against minors]: dissertatsia na soiskaniye nauchnoy stepeni kandidta yuridicheskikh nauk [dissertation for the scientific degree of $\mathrm{PhD}$ of Law].Odesa [in Ukrainian].

8. Dikunov, A.I. (2005). Kriminalisticheskiy analiz sledovoy kartiny rassleduemogo sobytiia s priznakami prestupleniia [Forensic analysis of a trace picture of an investigated event with signs of a crime]. dissertatsia dissertatsii na soiskaniye nauchnoy stepeni kandidta yuridicheskikh nauk [dissertation for the scientific degree of $\mathrm{PhD}$ of Law]. Moscow. [in Russian].

9. Krylov, I. V. (2010). Sovershenie prestupleniy v usloviiakh neochevidnosti [Committing crimes in conditions of non-obviousness]. Biznes $v$ zakone [Business in law], 5, 82-85 [in Russian].

10. Tkach, O. V. (2015). Slidova kartyna yak dzherelo dokazovoi informatsii pry rozsliduvanni porushen nedotorkannosti pryvatnoho zhyttia [The following picture as a source of evidentiary information in the investigation of violations of privacy]. Visnyk kryminalnoho sudochynstva [Bulletin of criminal proceedings], 4, 192-197. [in Ukrainian].

11. Kukharkov, Iu. V., Puchkov, G. F., Domoratskaiia, T. L., Tepliashina, I. S. (2001). Mediko-pravovye aspekty seksualnogo nasiliia [Medical and legal aspects of sexual violence]. Minsk. [in Russian].

12. Nikitina-Dudikova, H. Yu. (2015). Slidova kartyna nasylnytskoho zadovolennia statevoi prystrasti nepryrodnym sposobom, vchynenoho stosovno malolitnoi osoby [The following is a picture of the violent gratification of sexual passion in an unnatural way, committed against a minor]. Prykarpatskyi yurydychnyi visnyk [Prykarpattya Legal Bulletin], 3(2), 234-239. [in Ukrainian].

13. Perlin, S. I., Shevtsov, S. O., Kosmina, N. M., Ionova, V. V. (2009). Ohliad mistsia podii: vyiavlennia ta vyluchennia obiektiv biolohichnoho pokhodzhennia [Site survey: detection and seizure of objects of biological origin]. Kharkiv: Chaltsev O. V. [in Ukrainian].

14. Skorchenko, N. T. (2004). Rassledovanie iznasilovaniy [Rape investigation]. Moscow: Bylina. [in Russian].

15. Koldin, V. Ia. (eds.). (1985). Estestvennonauchnaia kriminalistika [Natural science forensics]. Moscow: Legal literature [in Russian].

16. Burchynskyi, V. H., Demianchuk, A. P., Khokholieva, T.V. (and others) (2012). Vykorystannia DNK-analizu u sudovo-medychnykh ekspertyzakh rechovykh dokaziv ta ekspertyzakh spirnoho batkivstva (materynstva, pidminy ditei) [The use of DNA analysis in forensic examinations of physical evidence and examinations of disputed paternity (maternity, substitution of children)]. Kyiv. [in Ukrainian].

17. Zatenatskiy, D. V. (2008). Idealnye sledy v kriminalistike [Ideal traces in forensics]. Problemy zakonnosti [Problems of legality], 78, 177-178, [in Russian].

18. Vekhov, V. B. (2008). Kriminalisticheskoe uchenie o kompiuternoy informatsii i sredstvakh ee obrabotki [Forensic science about computer information and means of its processing]: avtoreferat dissertatsii na soiskaniye nauchnoy stepeni doktora yuridicheskikh nauk [dissertation abstract for the scientific degree of Doctor of Law]. Volgograd [in Russian].

19. Hutsaliuk, M. V., Havlovskyi, V. D., Khakhanovskyi, V. H. (and others). (2020). Vykorystannia elektronnykh (tsyfrovykh) dokaziv u kryminalnykh provadzhenniakh [Use of electronic (digital) evidence in criminal proceedings]. Kyiv: NAVS [in Ukrainian].

20. Avdieieva, H. K., Storozhenko, S. V. (2017). Elektronni slidy: poniattia ta vydy [Electronic traces: concepts and types]. Visnyk Luhanskoho derzhavnoho universytetu vnutrishnikh sprav imeni E.O. Didorenka [Bulletin of Luhansk State University of Internal Affairs named after E.A. Didorenko], 1(77), 169-176. <https://journal.lduvs.lg.ua/index.php/journal/article/view/341> (2021, May, 18). [in Ukrainian]. 